\title{
Effect of Integrated Nutrient Management on Productivity of Maize (Zea mays L.) in Doon Valley Region
}

\author{
Tejavath Ramraju*, Sirazuddin and Roop Kishore Sharma
}

Department of Agronomy, Doon (pg) college of Agriculture and Allied Sciences, Rampur, Dehradun, Uttarakhand, India

*Corresponding author

\section{A B S T R A C T}

Keywords

Compost, Inorganic nutrient, Maize,

Nutrient

management,

Organic nutrient

Article Info

\section{Accepted:}

12 April 2021

Available Online:

10 May 2021
A field experiment was conducted during 2019 to 2020 at Dehradun, to study the effect of integrated nutrient management on productivity of maize (Zea mays L.) in doon valley region. The experiment was laid out in a randomized block design (RBD) in successive crop with 3 replications, consisting of 9 different treatments and the variety K-25. The results revealed that $50 \% \mathrm{RDF}+50 \%$ organic manure + zinc sulphate noticed significantly higher grain yield $(3280.67 \mathrm{~kg} / \mathrm{ha})$ over control and $100 \%$ recommended dose of fertilizer through chemical fertilizers (150:60:40 $\mathrm{kg} / \mathrm{ha}$ ) alone was found on par with rest of the treatments. Next best treatment was $75 \% \mathrm{RDF}+25 \%$ organic manure which recorded significantly higher grain yield $(3110 \mathrm{~kg} / \mathrm{ha})$ over treatment with control. The combined application of 50\% recommended dose of fertilizer $+50 \%$ organic manure + zinc sulphate showed higher significance in harvest index (23.88).

\section{Introduction}

Maize (Zea mays L.) is one of the important cereals which belongs to family Poaceace. It ranks third with regards to total world production among the cereals followed by wheat and rice and it is a principal staple food in many countries, particularly in the tropics and subtropics. Maize is considered as one of the most versatile crop which can be grown in diverse environment. The major maize producing countries in the world are USA, China, South and Central Africa, Argentina, Brazil and Mexico (Viswanath, 2019).

In cereals, Maize is cultivated throughout the year mainly due to photo-thermo-insensitive character hence it is known as "Queen of 
cereal". There are several factors that affect the productivity of maize: however, the fertilizer management is one of the most important factors that affect the growth and yield of maize (Verma, 2011).In India during the past 3 decades, intensive agriculture involving exhaustive high-yielding varieties of cereals has led to heavy withdrawal of nutrients from the soil.

The concept of integrated nutrient management has been found to be quite promising not only in maintaining higher productivity but also in providing greater stability in crop production (Nambiar and Abrol, 1992).Although chemical fertilizers supply few minerals to the soil, they impede the uptake of other nutrients and thereby upset the whole mineral balance pattern.

Integrated nutrient management plays an important role in sustainable agriculture by maintaining the productivity of crops in cereal based cropping sequences.

The chemical fertilizers are very costly and excessive use is harmful for soil health. Therefore, combination of organic manures with inorganic fertilizers has found to be beneficial to maximize the crop productivity and improve soil properties (Verma et al., 2002). (Gaur and Kumawat2000) reported that combination of organic manure and chemical fertilizer produced higher yield and improved soil fertility in maize-wheat cropping sequence.

Organic manures such as poultry manure and farmyard manure are important components of integrated nutrient management. Organic manures supply the traces amount of micronutrients, which are generally not supplied by the farmers as straight fertilizers.

Organic farming is, therefore, the only remedy, which should be encouraged in order to lower down the cost of inputs and to improve soil health. The use of organic manures like FYM and poultry manure not only helps to maintain the soil productivity by improving the physico-chemical properties of soil but also improves the efficiency of applied chemical fertilizers. It counteracts the ill effects of chemical fertilizers applied to the soil by way of reducing chemical toxicity to the microbes and thereby favours their growth.

Besides this, organic manure improves the water holding capacity and cation exchange capacity of the soil, which results into smooth supply of nutrients to the crop plants and finally results into profitable yields. The information on the combined impact of organic and inorganic fertilizers in different proportions is not available for the maize growers of this region.

\section{Materials and Methods}

The present study was conducted at Agriculture research farm. Doon College of Agriculture allied sciences and technology, Dehradun (U.K.). The experiment entitled "Effect of integrated nutrient management on productivity of maize (Zea mays L.) in doon valley region" was conducted in rabi season of 2019. The material used and the methodology adopted to carry out this research are being presented. The experiment consisting of 9 treatments was laid out in a Randomized block design with 3 replications. Treatments are (T1) control, (T2) 100\% RDF, (T3) 75\% RDF, (T4) $50 \%$ RDF, (T5) $75 \% \mathrm{RDF}+25 \%$ Organic Manure, (T6) $50 \%$ RDF $+50 \%$ Organic Manure, (T7) $75 \% \mathrm{RDF}+25 \%$ Organic Manure + Zinc Sulphate, (T8) $100 \%$ RDF + Zinc Sulphate and (T9) 50\% RDF + $50 \%$ Organic Manure + Zinc Sulphate. The variety K-25 of maize was sown according to the treatments and replications, maintaining row to row spacing of $15 \mathrm{~cm}$ and plot to plot $0.5 \mathrm{~m}$ with seed rate of $20 \mathrm{~kg} \mathrm{ha}^{-1}$. 


\section{Results and Discussion}

\section{Growth parameter}

Data on plant height recorded at different stages of 30, 60 and 90 DAS. At each stage, the plant height shown significantly tallest plant was recorded with application of $75 \%$ recommended NPK (150:60:40 kg ha) + 25\% organic manure + zinc sulphate at 30 DAS, $100 \%$ recommended NPK at 60 DAS and 50\% recommended NPK $+50 \%$ organic matter + zinc sulphate at 90 DAS of $48.94 \mathrm{~cm}, 183.04$ $\mathrm{cm}$ and $201.51 \mathrm{~cm}$. Generally, plant height (cm) of maize increased upto the stage of harvest due to the application of various stages of nutrients. There was significant and consistent increase in plant height in maize except at knee high stage with increase in fertility level (Singh and Dubey 1991). Plant density differed significantly due to application of organic and inorganic nutrient sources. Among the different combinations of nutrient sources, the application 50\% recommended NPK $+50 \%$ organic manure (6.67 sq. mt) recorded significantly highest than remaining treatments. The plant density was found to increase before 30 days from beginning up to the harvest stage. Fresh weight was enriched with the age of plant growth upto the harvest stage.

The treatments $100 \%$ recommended NPK through chemical fertilizer showing significantly highest (70.33 g) at $30 \mathrm{DAS}$, that the treatment $50 \%$ recommended NPK $+50 \%$ organic manure + zinc sulphate $(359.45 \mathrm{~g})$ at 60 DAS and treatments $50 \%$ recommended $\mathrm{NPK}+50 \%$ organic manure + zinc sulphate (477.94 g) showing highest significant at 90 DAS.

Similarly, the data recorded in dry weight at various treatments, at $30 \mathrm{DAS}$, application of $50 \%$ recommended NPK $+50 \%$ organic manure significantly recorded maximum leaf dry matter $(6.70 \mathrm{~g})$. At 60 DAS, significantly maximum $(53.91 \mathrm{~g})$ leaf dry matter recorded with $50 \%$ recommended NPK $+50 \%$ organic manure +zinc sulphate through chemical fertilizers and at harvest stage leaf dry weight is followed by increasing trend compared to 60 DAS, where application of $50 \%$ recommended NPK $+50 \%$ organic manure + zinc sulphate $(74.83 \mathrm{~g})$ significantly maximum leaf dry weight.

The fresh weight and dry weight was found to increase before 30 days period of growth and the slow increment continued till the harvest stage. Such type of variations among the growth parameters may be due to the fact these are genetically governed and varies with the type and variety of plants grown (Kumar and Singh 1992). Leaf area index is one of the important parameter, the data was recorded at different stages at different combinations of organic and inorganic nutrient sources. At 30 DAS, significantly maximum LAI (0.56) was recorded with $75 \%$ recommended NPK $+25 \%$ organic manure + zinc sulphate. At 60 DAS, maximum LAI (1.36) was significantly recorded due to application of $100 \%$ recommended NPK and at harvest, also application of $100 \%$ recommended NPK (1.53) recorded significantly higher leaf area index.

Leaf area index increased from 30 DAS to 60 DAS and there was a sheer fall there after from 60 DAS to harvest. Increased in leaf area index up to 60 DAS could be due to production and maintenance of more green leaves and reduction from thereafter was mainly because of senescence of leaves (Misra et al., 1994). The number of leaves per plant is the important growth parameter because leaf is the factory for conversion of solar energy into chemical energy by the process of photosynthesis. The number of leaves increased between 30 DAS due to fast vegetative growth of plant during this period. 
Table.1 Growth parameters of maize variety K-25 as influenced by different fertilizer levels and organic manure at various growth stages

\begin{tabular}{|c|c|c|c|c|c|c|c|c|c|c|c|c|c|c|c|c|c|}
\hline \multirow[t]{2}{*}{$\begin{array}{c}\text { Treatment } \\
\text { No. }\end{array}$} & \multirow[t]{2}{*}{ Treatments } & \multicolumn{3}{|c|}{ Plant height (cm) } & \multirow{2}{*}{$\begin{array}{c}\begin{array}{c}\text { Plant } \\
\text { density } \\
\text { (sq. mt) }\end{array} \\
\text { Plant } \\
\text { density } \\
\text { (sq. mt) }\end{array}$} & \multicolumn{3}{|c|}{ Fresh weight (g) } & \multicolumn{3}{|c|}{ Dry weight (g) } & \multicolumn{3}{|c|}{ Leaf area index } & \multicolumn{3}{|c|}{$\begin{array}{c}\text { Number of leaves per } \\
\text { plant }\end{array}$} \\
\hline & & $\begin{array}{c}\text { 30 } \\
\text { DAS }\end{array}$ & $\begin{array}{c}60 \\
\text { DAS }\end{array}$ & $\begin{array}{c}\text { At } \\
\text { harvest }\end{array}$ & & $\begin{array}{c}30 \\
\text { DAS }\end{array}$ & $\begin{array}{c}60 \\
\text { DAS }\end{array}$ & $\begin{array}{c}\text { At } \\
\text { harvest }\end{array}$ & $\begin{array}{c}30 \\
\text { DAS }\end{array}$ & $\begin{array}{c}60 \\
\text { DAS }\end{array}$ & $\begin{array}{c}\text { At } \\
\text { harvest }\end{array}$ & $\begin{array}{c}30 \\
\text { DAS }\end{array}$ & $\begin{array}{c}\text { 60 } \\
\text { DAS }\end{array}$ & $\begin{array}{c}\text { At } \\
\text { harvest }\end{array}$ & $\begin{array}{c}30 \\
\text { DAS }\end{array}$ & $\begin{array}{c}60 \\
\text { DAS }\end{array}$ & $\begin{array}{c}\text { At } \\
\text { harvest }\end{array}$ \\
\hline T1 & Control & 40.68 & 143.69 & 177.017 & 4.67 & 34.79 & 144.997 & 317.133 & 3.5 & 24.52 & 44.33 & 0.25 & 0.9 & 1.03 & 5.67 & 9.67 & 19.33 \\
\hline $\mathbf{T} 2$ & $100 \% \mathrm{RDF}$ & 48.56 & 183.04 & 193.96 & 3.67 & 70.33 & 352.707 & 457.263 & 5.14 & 53.44 & 72.19 & 0.53 & 1.36 & 1.5333 & 7.67 & 12.33 & 24.33 \\
\hline T3 & $75 \%$ RDF & 44.2 & 176.92 & 193.667 & 6 & 54.15 & 249.807 & 388.843 & 4.48 & 42.49 & 63.8 & 0.35 & 1.073 & 1.2267 & 8.33 & 11.33 & 21.33 \\
\hline T4 & $50 \% \mathrm{RDF}$ & 43.6 & 152.35 & 186.3 & 5.67 & 60.38 & 294.77 & 366.73 & 3.953 & 50.67 & 63.417 & 0.3 & 1.12 & 1.14 & 7.67 & 10.33 & 20 \\
\hline T5 & $\begin{array}{c}75 \% \mathrm{RDF}+ \\
25 \% \mathrm{OM}\end{array}$ & 47.6 & 149.36 & 188.747 & 5.67 & 63.78 & 331.22 & 451.27 & 5.9 & 53.19 & 62.94 & 0.43 & 1.12 & 1.1733 & 5 & 13.67 & 21 \\
\hline T6 & $\begin{array}{c}50 \% \mathrm{RDF}+ \\
50 \% \mathrm{OM}\end{array}$ & 44.78 & 159.55 & 194.227 & 6.67 & 57.22 & 281.3 & 382.733 & 6.703 & 41.66 & 60 & 0.37 & 0.867 & 1.26 & 8.33 & 12.33 & 19.33 \\
\hline T7 & $\begin{array}{c}75 \% \text { RDF + } \\
25 \% \text { OM + } \\
\text { Zinc Sulphate }\end{array}$ & 48.94 & 167.79 & 194.927 & 5 & 64.57 & 341.743 & 452.303 & 4.867 & 51.07 & 67.887 & 0.56 & 0.967 & 1.3367 & 8.33 & 14.33 & 19.33 \\
\hline T8 & $\begin{array}{l}100 \% \text { RDF + } \\
\text { Zinc Sulphate }\end{array}$ & 44.92 & 158.59 & 194.163 & 5.33 & 49.7 & 295.63 & 367.977 & 4.557 & 44.62 & 55.49 & 0.41 & 1.05 & 1.1533 & 5.33 & 11.33 & 18.33 \\
\hline T9 & $\begin{array}{c}50 \% \text { RDF + } \\
50 \% \text { OM + } \\
\text { Zinc Sulphate }\end{array}$ & 47.1 & 115.93 & 201.51 & 5.67 & 66.45 & 359.45 & 477.947 & 5.577 & 53.91 & 74.837 & 0.56 & 1.153 & 1.4367 & 7.33 & 14.67 & 23.33 \\
\hline & SEm \pm & 0.71 & 17.34 & 1.693 & 0.46 & 0.39 & 4.65 & 9.027 & 0.215 & 0.497 & 0.731 & 0.01 & 0.047 & 0.008 & 0.29 & 0.5 & 0.99 \\
\hline & $\operatorname{CD}(5 \%)$ & 2.13 & 51.984 & 5.076 & 1.38 & 1.17 & 13.94 & 27.059 & 0.646 & 1.49 & 2.191 & 0.03 & 0.142 & 0.023 & 0.86 & 1.485 & 2.96 \\
\hline
\end{tabular}


Table.2 Yield parameters of maize variety K-25 as influenced by different fertilizer levels and organic manure at various growth stages

\begin{tabular}{|c|c|c|c|c|c|c|}
\hline $\begin{array}{c}\text { Treatment } \\
\text { No. }\end{array}$ & Treatments & $\begin{array}{c}\text { Number of } \\
\text { cobs per } \\
\text { plant }\end{array}$ & $\begin{array}{c}\text { Number of } \\
\text { grains per } \\
\text { cob }\end{array}$ & $\begin{array}{c}\text { Cob weight } \\
\text { (g) }\end{array}$ & $\begin{array}{c}\text { Grain yield } \\
\text { (kg/ha) }\end{array}$ & Harvest index \\
\hline T1 & Control & 1.33 & 156 & 79.49 & 1665.67 & 22 \\
\hline $\mathbf{T 2}$ & $100 \% \mathrm{RDF}$ & 1.67 & 254 & 143.73 & 3075.67 & 22.61 \\
\hline T3 & $75 \% \mathrm{RDF}$ & 1 & 202 & 129.74 & 2454.67 & 22.96 \\
\hline T4 & $50 \% \mathrm{RDF}$ & 1.33 & 189 & 134.93 & 2468.67 & 23.16 \\
\hline T5 & $75 \% \mathrm{RDF}+25 \% \mathrm{OM}$ & 1.33 & 223.33 & 134.68 & 3110 & 23.85 \\
\hline T6 & $50 \% \mathrm{RDF}+50 \% \mathrm{OM}$ & 1.33 & 165.67 & 121.5 & 1965.33 & 21.7 \\
\hline $\mathbf{T 7}$ & $75 \%$ RDF + $25 \%$ OM + Zinc Sulphate & 1 & 206.33 & 138.87 & 2952.67 & 23.25 \\
\hline T8 & $100 \%$ RDF + Zinc Sulphate & 1.33 & 169 & 122.75 & 2407.33 & 22.54 \\
\hline \multirow[t]{3}{*}{ T9 } & $50 \% \mathrm{RDF}+50 \% \mathrm{OM}+$ Zinc Sulphate & 2.33 & 249.67 & 143.11 & 3280.67 & 23.88 \\
\hline & SEm \pm & 0.38 & 5.62 & 5 & 72.66 & 0.32 \\
\hline & CD (5 \%) & 1.13 & 16.86 & 14.98 & 217.82 & 0.97 \\
\hline
\end{tabular}


The number of leaves at 30 DAS, was found to be highest in treatments $75 \%$ recommended NPK (8.33), at 60 DAS, highest number of leaves eas recorded under $50 \%$ recommended $\mathrm{NPK}+50 \%$ organic manure + zinc sulphate (14.67) and at harvest stage the treatment $100 \%$ recommended NPK (24.33) recorded significant by higher number of leaves. Number of leaves per plant, a vital photosynthetic character, was found to increase significantly with treatments $50 \%$ $\mathrm{RDF}+50 \%$ organic manure, $75 \% \mathrm{RDF}+25 \%$ organic manure + zinc sulphate and $75 \% \mathrm{RDF}$ at $30 \mathrm{DAS} .50 \% \mathrm{RDF}+50 \%$ organic manure + zinc sulphate at 60 DAS and $100 \%$ RDF at harvest which in turn also differed significantly. Number of leaves per plant increased from 30 to 60 DAS, but declined marginally during 60 DAS because of the 3-4 leaves ceased to be functional due to senescence and there was a steep fall there after harvest. Decline in the number of leaves after growth period could be due to the results of senescence of older leaves (Singarma and Kothandramnan 1993).

\section{Yield parameters}

Number of cobs per plant is important parameter that affects by various treatments. The treatment $50 \%$ recommended $+50 \%$ organic manure + zinc sulphate (2.33) recorded non significance difference. However, the number of cobs per plant could be increased significantly with treatment $50 \%$ $\mathrm{RDF}+50 \%$ organic manure + zinc sulphate (Misra et al., 1994). As, the number of grains per cob is one of the most important contributing character in maize crop. The data recorded to number of grains per cob as influenced by various treatments. Application of $100 \%$ recommended NPK (254.00) through chemical fertilizers recorded maximum number of grains per cob. Cob weight differs from treatment to treatment only one treatment can show the highly significant among all treatments. Maximum weight of cob (143.11 g) was observed with $50 \%$ recommended NPK $+50 \%$ organic manure + zinc sulphate through organic and chemical fertilizers. Weight of cob due to application of various nutrient sources differed significant. Maize plant grown under $50 \% \mathrm{RDF}+50 \%$ organic manure + zinc sulphate had significantly higher cob weight per plant compared to other treatments. Healthy plant were produced due to more availability of nutrients with maximum number of cobs and ovule, filled enough with starch after fertilization. The continuous filling of kernels with sufficient photosynthates led to increased size of cob it results in increased the cob weight this findings was also in accordance with (Singh and Vyas 1995) and (Krishna et al., 1998).Grain yield (kg/ha) was influenced significantly by different combinations of organic and inorganic nutrient sources. Higher grain yield $(3280.67 \mathrm{~kg} / \mathrm{ha})$ was obtained by application of $50 \%$ recommended NPK $+50 \%$ organic manure + zinc sulphate through organic and chemical fertilizers. Grain yield is the net result of various agronomic inputs influencing growth and yield attributing characters during the life cycle of the crop. The increase in maize grain yield with increasing fertility levels was mainly due to its better contribution towards different yield contributing characteristics (Pal et al., 1998) also reported that maize yield significantly increased with increasing applications of chemical fertilizers NPK. However the treatment receiving $50 \% \mathrm{RDF}+50 \%$ organic manure + zinc sulphate (23.88) recorded more harvest index through chemical fertilizers and organic manure. The plant growth is completely depend upon the nutrient supplying capacity of soil right from its seedling stage to commencement of reproductive phase. This nutrient supplying capacity of soil was improved by the application of various sources of nutrients such as organic manures and inorganic 
fertilizers besides improvement in physical, chemical and biological properties of soil. The availability of major and micro nutrients releasing nature of these sources, which in turn decided by nature and composition by means of $\mathrm{C}: \mathrm{N}$ ratio of manure (Madhavi et al., 1995), (Rameshwar 1998). The harvest index was maximum in $50 \% \mathrm{RDF}+50 \%$ organic manure + zinc sulphate (23.88) followed by $75 \% \mathrm{RDF}+25 \%$ organic manure (23.85) (Kapoor et al., 1999), (Singaram and Kamala kumari 1993) and (Chandrashekara 2000).

\section{References}

Chandrashekara (2000). Response of maize (Zea mays L) to organic manures with inorganic fertilizers. Karnataka Journal of Agril. Sciences, 13(1): 144-146.

Gaur, B. L. and S. K. Kumawat (2000). Integrated nutrient management in maize-wheat cropping system under South Rajasthan condition. In: National Symposium on Agronomy - challenges and strategies for the new millennium, held at GAU campus, Junagarh (Gujarat), 15-18 Nov., pp.55-56.

Kapoor, K. K. and K. K. Nayak (1999). Soil nitrogen balance as influenced by enriched farm yard manure and fertilizer nitrogen levels in maize (Zea mays L.) production. Mysore J. Agric. Sci., 37(1): 29-33.

Krishna, A., S. V. Raikhelkar and A. S. Reddy (1998). Effect of planting pattern and nitrogen on fodder maize . (Zea mays) intercropped with cowpea (Vigna unguiculate). Indian J. Agron., 43(2): 237240.

Kumar, S. and R. P. Singh (1992). Cob characteristics and soybean yield in maizelegume intercropping systems. Haryana Journal of Agron.,8(1): 38-43.
Madhavi, B. L., M. S. Reddy and P. C. Rao (1995). Integrated nutrient management using poultry manure and fertilizer. J. Res. Andhra Pradesh Agric. Univ., 23(3-4):1-4.

Misra, B. N., R. S. Yadav, A. 1. Rajput and S. M. Pandey (1994). Effect of plant geometry and nitrogen application on yield and quality of winter maize. Indian J.Agron.,39(3): 468469

Pal, U. R.., B. A. Kalu, J. C. Norman and D. K. Adedzwa (1998). Nitrogen and phosphorus fertilizer use in soybean- maize mixture. Journal of Agron. and Crop Science, 160(2):132-140.

Rameshwar and C. M. Singh (1998). Nutrient management for yield maximization in maize (Zea mays)-wheat system under rainfed mid hill condition of H.P. Himachal. J. of Agricultural Research, Publ.1999, 24(1 -2): 11-19.

Singh, U. K. and O. P. Dubey (1991). Response of maize to the application of nitrogen and phosphorus. Current Res.,28(8): 153-154.

Singaram, P. and K. Kamalakumari (1993). Effect of continuous manuring and fertilization on maize grain quality and nutrient soil enzyme relationship. Madras Agricultural Journal, Pub/., 2000, 86(1-3): 51-54

Singh, A. and A. K. Vyas (1995). Effect of nitrogen and zinc application on growth, yield and net returns of maize (Zea mays). Annals of Agric.Res.,21(2): 296-297.

Verma, N. K. (2011). Integrated nutrient management in winter maize (Zea mays L.) sown at different dates. Journal of Plant Breeding and Crop Science, 3(8): 161-167.

Viswanath, K. R., Sharma, R. K. and Mallikarjuna, G. (2019). Effect of organic and inorganic manures on $\mathrm{n}, \mathrm{p}$ and $\mathrm{k}$ content in grain and straw at harvest of maize. Journal of Pharmacognosy and Phytochemistry, 8(4): 2475-2478.

\section{How to cite this article:}

Tejavath Ramraju, Sirazuddin and Roop Kishore Sharma. 2021. Effect of Integrated Nutrient Management on Productivity of Maize (Zea mays L.) in Doon Valley Region. Int.J.Curr.Microbiol.App.Sci. 10(05): 341-347. doi: https://doi.org/10.20546/ijcmas.2021.1005.041 